\section{OPEN OACCESS}

DOI: $10.25040 / n t s h 2019.01 .15$

Для листування:

м. Львів, вул. Пекарська, 69, 79010

Е-пошта: bula.nazar@gmail.com

Стаття надійшла: 14.03 .2019

Прийнята до друку: 08.05.2019

Опублікована онлайн: 26.06.2019

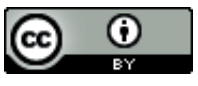

(c) Н. Була, Ю. Шаваров, Я. Савицький,

М. Савицька, 2019

ORCID ID

Nazar Bula

https://orcid.org/0000-0001-6676-6234 Yurij Shavarov

https://orcid.org/0000-0001-5373-8699

Yaroslav Savytskyi

https://orcid.org/0000-0002-2399-2095

Maryanna Savytska

https://orcid.org/0000-0001-9404-4589

Конфлікт інтересів: Автори декларують

Внесок авторів:

Ідея: Н. Була

Написання статті: I. Паляниця. варіанту статті: Н. Була, М. Савицька. відсутність конфлікту інтересів.

Дослідження: Н. Була, Ю. Шаваров.

Редагування і затвердження остаточного

\section{Досвід малоінвазивних - ендоскопічних методів зупинки коровотеч з верхніх відділів травної системи}

\author{
Назар Була',2, Юрій Шаваров², Ярослав Савицький, \\ Мар'яна Савицька ${ }^{1}$ \\ Львівський національний медичний університет імені \\ Данила Галицького ${ }^{1}$ \\ КНП ЛОР Львівська обласна клінічна лікарня ${ }^{2}$
}

Вступ. За останні десятиліття значно зросла кількість малоінвазивних хірургічних втручань як в плановій хірургії так і в ургентній ендоскопічній хірургії. 3 розвитком сучасних відеоендоскопічних систем активно розвиваються ендоскопічні інструменти та аксесуари для виконання ендоскопічних операцій. Сучасною розробкою у вигляді сухої форми гемостатичного клею - неорганічного походження, що 3 допомогою аерозолю доставляється ендоскопічним методом $\epsilon$ Hemosprey, фірми Cook, препарат сертифікований та широко використовується в країнах Європейського Союзу, Канаді та США з 2011р. Коли порошок контактує з кров'ю, він поглинає воду і утворює гель, який діє когезивно і адгезивно, створюючи стабільний механічний бар>єр, який охоплює місце кровотечі. Дана методика ще не поширена в Україні, тому нами зроблена спроба вивчити ефективність даного препарату в умовах регіональної лікарні. Актуальність проблеми підкреслює висока захворюваність середнє число госпіталізацій з приводу кровотеч складає 1 на 1000 населення. В залежності від етіологічного фактора, летальність досягає від 3 до 50\%. Загальна летальність при шлунково-кишкових кровотечах у місті Києві складає 3,1\%, по Україні в цілому - 8,5\%. Серед пацієнтів переважають люди працездатного віку.

Мета роботи. Вивчити ефективність методу зупинки кровотечі за допомоги Hemospray в умовах ендоскопічного втручання. Дослідити ефективність використанням гемостатичного клею як методу моногемостазу, так і в комплексі з іншими ендоскопічними методами ендогемостазу кровотеч ШКТ.

Матеріали та методи. До когорти спостереження ввійшло 7 пацієнтів (чоловіків 5, жінок 2), віком 28-79 років (середній вік 52士7,1 років), які на першому етапі лікувались у Львівській обласній клінічній лікарні, хірургічному відділенні №3, хірургічному відділенні №2 а на другому - у гастроентерологічному відділенні ЛОКЛ в період з 2018 до 2019 рр. Використовували відеоендоскоп Fujinone-250, кліпатори Hemoclips виробник Olympus, засіб порошкового гемостазу Hemosprey виробник Cook При зупинці кровотечі за рішенням хірурга-ендоскопіста порошковий гемостаз комбінувався з кліпуванням джерела кровотечі.

Результати. Результатом наведеного ендоскопічного гемостазу з допомогою засобу Неmospray як при монометоді, так і в комплексі з ендоскопічним кліпування з подальшою консервативною терапією врятувало від ургентних хірургічних втручань та зберегло життя 7 хворих. В жодного із пацієнтів не було рецидиву кровотечі. Пацієнти були із різною етіологією та причиною кровотеч ШКТ. 100\% хворих яким був проведений ендоскопічний гемостаз засобом Hemospray дав позитивний ефект. 


\title{
The experience of minimally invasive - endoscopic methods used to stop bleeding in upper sections of the digestive system.
}

\author{
Bula N. 1,2, Shavarov Yu. ${ }^{2}$, Savytskyi Ya. ${ }^{1}$, \\ Savytska M. ${ }^{1}$ \\ Lviv Danylo Halytsky National Medical University ${ }^{1}$ \\ Lviv Regional Clinical Hospital ${ }^{2}$
}

Introduction. Over the past decade, the number of minimally invasive surgical interventions both in the scheduled and urgent endoscopic surgery has increased significantly. With the development of modern video endoscopic systems, endoscopic surgical tools and accessories have been actively developing. A modern development is Hemosprey from Cook, which is certified and has been widely used in the countries of the European Union, Canada, and the USA since 2011. It is provided in the form of dry hemostatic glue of inorganic origin, which is endoscopically delivered with the help of aerosol. When the powder contacts with blood, it absorbs water and creates a gel that acts as a cohesive and adhesive by creating a stable mechanical barrier around the bleeding site. This methodology is not common in Ukraine, therefore we have made an attempt to study the efficiency of this drug in the regional hospital setting. The relevance of this issue is highlighted by the high morbidity among the population - an average number of people hospitalized with bleeding constitutes 1 per 1000 people. Depending on the etiological factor, the mortality rate is $3-50 \%$. The general mortality rate in case of gastrointestinal bleeding constitutes 3.1\% in Kyiv and $8.5 \%$ - generally in Ukraine. Among patients, the working-age population prevails.

The aim. To study the efficiency of the method used to stop bleeding using Hemospray in the settings of endoscopic intervention. To research the efficiency of using hemostatic glue both as a mono-method and in combination with other endoscopic methods for endo-hemostasis of gastrointestinal bleeding.

Materials and methods. The observed cohort included 7 patients ( 5 men, 2 women) aged 2879 (average age - 52 \pm .1 ), who during the first stage received treatment at Lviv Regional clinical hospital, surgery department No. 3, surgery department No. 2, and during the second stage in 2018-2019 - at the gastroenterological department of Lviv Regional Clinical Hospital. Video endoscope Fujinone-250, clipping devices Hemoclips from Olympus, Hemosprey preparation for hemostasis, manufacturer - Cook. When the bleeding stopped, powder hemostasis was combined with clipping of the bleeding source upon the surgeon-endoscopist's decision.

Results. This endoscopic hemostasis using Hemospray resulted in the avoidance of urgent surgery and saved the lives of 7 patients both when used as a mono-method and when combined with endoscopic clipping with subsequent conservative therapy. None of the patients had recurrent bleeding. Patients had various etiology and causes of gastrointestinal bleeding. $100 \%$ of patients that were treated with the endoscopic hemostasis using Hemospray had a positive effect. 


Original research: Clinical sciences

Висновки. Засі6 Hemospray свідчить про високу ефективність зупинки ургентних кровотеч з органів верхніх відділів травної системи використовуючи Hemospray, як при моногемостазі, так і в комплексі із іншими ендоскопічними методами. [ 1,10$]$. Hemospray має наступні ключові переваги над іншими ендоскопічними методами : безтермічний - немає термічного контакту із тканинами, що унеможливлює високий ризик ускладнень; нетравматичний - оскільки на місці зупинки кровотечі не прикладається жодна сила зводиться до нуля ризик травми тканин; безконтактний - аерозольна система доставки виключає необхідність прямих механічних та контактних сил; безпечний у вжитку - одноразові канюлі, що йдуть в комплекті - зводять до нуля ризик передачі трансмісивних інфекційних захворювань при контакті з кров'ю; зручність та легкість у використанні - порошок розпорошується до джерела кровотечі, тому він не вимагає підходу in face та точного націлювання зокрема важливо при роботі у важкодоступних місцях $[2,4,6]$.

Ключові слова: відеогастроскопія, шлунково-кишкові кровотечі, ендоскопічний гемостаз, ендоскопічні методи зупинки кровотеч, класифікація кровотеч Forrest, Hemospray.

Вступ. Кровотечі із органів шлунково-кишкового тракту (ШКТ) - це одна із найчастіших причин госпіталізації хворих в ургентному порядку в хірургічний стаціонар [3, 7, 12]. Кровотечі у ШКТ поділяються за анатомічною локалізацією на: верхні - близько 90 \% випадків (всі органи що розташовані вище зв'язки Трейца) та кровотечі з нижнього відділу ШКТ, що присутні у $10 \%$ пацієнтів, (нижче зв'язки Трейца). Найчастіші причини кровотеч із верхніх відділів ШКТ $€$ : виразка дванадцятипалої кишки, гостра геморагічна (ерозивна) гастропатія, виразка шлунку, варикозно розширені вени стравоходу, синдром Меллорі-Вейса, інші (рідше) - езофагіт або дуоденіт, пухлини, виразки стравоходу і судинні мальформації. Перші 3 причини займають близько 60 \% усіх госпіталізованих з цього приводу пацієнтів. Найчастішою причиною кровотеч із нижніх відділів ШКТ $є$ дивертикули товстого кишки, пухлини, рідше - запальні захворювання кишки із ерозуванням та виразкуванням, варикозно розширені гемороїдальні вени, новоутвори і судинні мальформації, а у дітей - інвагінації, запальні захворювання кишки, запалення дивертикулу Меккеля і поліпи тонкої або товстої кишки $[13,19,20,21]$.

Одну з ключових позицій у діагностиці і лікуванні хворих зі ШКТ в даний час займає відегастроскопія. Саме впровадження ендоскопічних методик дозволяє більш, ніж у 90\% випадків зупиняти кровотечу під час первинного огляду і, тим самим, зменшити кількість екстрених операцій при яких спостерігається найбільш висока летальність $[5,8,9]$. У зв>язку з цим, широке впрова- дження одержала ендоскопічна класифікація активності кровотеч, що запропонована Forrest J.A.H., Rosch W. ,1987 (таб. 1)

Таблиця 1

\section{Ендоскопічна класифікація кровотеч із верхніх відділів шлунково- кишкового тракту зa Forrest J.A.H., Rosch W. (1987)}

\begin{tabular}{|l|l|}
\hline \multicolumn{2}{|c|}{$\begin{array}{c}\text { Ендоскопічна класифікація кровотеч } \\
\text { за Forrest et al., 1987 }\end{array}$} \\
\hline Forrest IA & пульсуюча, струменева кровотеча \\
\hline Forrest IB & капілярна, краплинна кровотеча \\
\hline Forrest IIA & видима тромбована судина \\
\hline Forrest IIB & фіксований тромб \\
\hline Forrest IIC & гематин на дні виразки \\
\hline Forrest III & виразка з чистим дном, фібрином \\
\hline
\end{tabular}

Саме від вчасно виконаної діагностично-лікувальної ендоскопії буде залежати подальша тактика ведення пацієнта та алгоритм лікування $[14,15,16]$. Згідно рекомендацій Европейської Асоціації Гастроентерологів під час кровотечі ШКТ повинна бути виконана ургентна відеогастроскопія та зроблена спроба ендоскопічної зупинки кровотечі з оцінюванням ризиків рецидиву кровотечі (рис. 1)

Сучасні ендоскопічні методи зупинки кровотеч включають наступні варіанти: електрокоагуляційні методи (аргоновоплазмова коагуляція), кліпування, лігування, обколювання (ін'єкційна гемотерапія) та використання гемостатичних клейких спреїв (рис.2). 
Conclusions. Hemospray shows a high efficiency when it comes to stopping urgent bleeding from upper sections of the digestive system with the help of Hemospray both as a mono-method or in combination with other endoscopic methods. [ 1, 10]. Hemospray has the following key benefits over other endoscopic methods: non-thermal - there is no thermal contact with tissues, which makes it impossible for the high risk of complications to appear; non-traumatic - since no pressure is exerted to stop bleeding, the risk of tissue injury is reduced to zero; Contactless - aerosol delivery system presupposes the need for direct mechanical and contact force; safe - disposable cannulas that come as part of the kit - minimize the risk of infectious disease transmission when contacted with blood; Convenience and ease of use - the powder is used on the source of bleeding, therefore it does not require the in face approach and accurate targeting, which is especially important when working in hard-to-reach places $[2,4,6]$.

Keywords: Video gastroscopy, gastrointestinal bleeding, endoscopic hemostasis, endoscopic methods used to stop bleeding, Forrest qualification of bleeding, Hemospray.

Introduction. Bleeding from the organs of the gastrointestinal tract (GIT) is one of the most frequent causes of urgent hospitalization of patients in the surgical department [3, $7,12]$. GIT bleeding is divided based on its anatomic localization: top - about $90 \%$ of cases (all organs located above the Treitz ligament) and bleeding from the bottom part of the GIT, experienced by $10 \%$ of patients (below the Treitz ligament). The most common causes of bleeding from upper GIT sections are duodenal ulcer, acute hemorrhagic (erosive) gastropathy, gastric ulcer, esophagus varicosity, Mallory-Weiss syndrome, other (on a more rare basis) - esophagitis or duodenitis, tumors, esophageal ulcers, and vascular malformations. The first three causes account for $60 \%$ of all patients hospitalized because of this. The most common cause of bleeding from the bottom GIT sections are coIon diverticulosis, tumors, and more rarely inflammatory intestine disease with erosions and ulcers, varicosity of hemorrhoidal veins, neoplasms, and vascular malformations; in children, these are invaginations, inflammatory intestine disease, Meckel's diverticulum inflammation, large and small intestine polyps $[13,19,20,21]$.

Video gastroscopy currently occupies one of the key roles in the diagnostics and treatment of patients with GIT diseases. The implementation of endoscopic methodologies enables to stop bleeding during the first examination in over $90 \%$ of cases. This allows stopping the number of urgent surgeries with a high mortality rate $[5,8,9]$. This results in the wide implementation of endoscopic classification of bleeding activity, which was suggested by Forrest J.A.H., Rosch W., 1987 (Table 1)

Table 1

\section{Endoscopic classification of bleedings from the upper section of the gastroin- testinal tract according to Forrest J.A.H., Rosch W. (1987)}

\begin{tabular}{|l|l|}
\hline \multicolumn{2}{|c|}{$\begin{array}{c}\text { Endoscopic classification of bleedings } \\
\text { according to Forrest et al., 1987 }\end{array}$} \\
\hline Forrest IA & Throbbing, spurting bleeding \\
\hline Forrest IB & Capillary, dripping bleeding \\
\hline Forrest IIA & Visible thrombosed vessel \\
\hline Forrest IIB & Anchored blood clot \\
\hline Forrest IIC & Hematin on the bottom of the ulcer \\
\hline Forrest III & Ulcer with a clear bottom, fibrin \\
\hline
\end{tabular}

Further tactics of patient maintenance and treatment algorithm depend on the timely completed diagnostic and treatment endoscopy $[14,15,16]$ According to the recommendation of the United European Gastroenterology, in case of bleeding from the GIT, urgent video gastroscopy must be performed and an attempt to stop bleeding endoscopically must be made while assessing the risks of bleeding relapse (Figure 1)

Modern endoscopic methods used to stop bleeding include the following: electro coagulating methods (argon plasma coagulation), clipping, ligation, injectable hematotherapy and hemostatic adhesive sprays (Figure 2). 


\section{Ризик рецидиву кровотеч в залежності від стадії за Forrest}

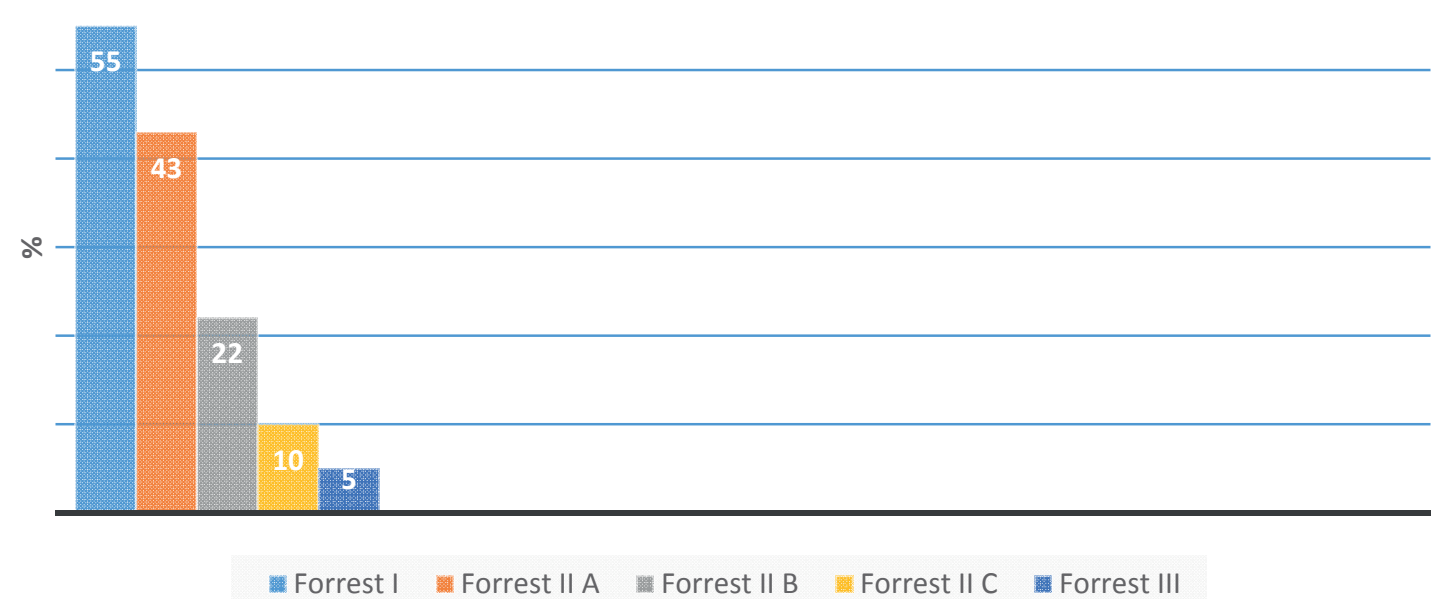

Рис. 1. Ризик рецидиву кровотечі в залежності від ступеня важкості за Forrest (Laine \& Peterson WL.N. Engl. Med. 1994;331:717-27)

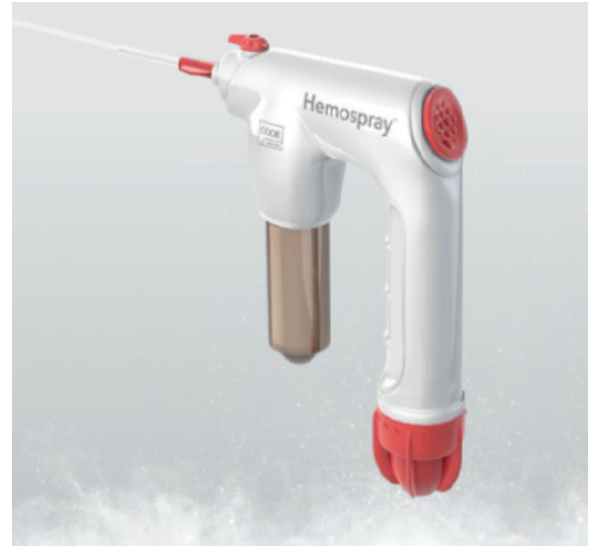

Рис. 2. Hemospray - спрей для ендогемостазу

Мета роботи. Вивчити ефективність методу зупинки кровотечі за допомоги Hemospray в умовах ендоскопічного втручання. Описати ефективність такого способу втручання з використанням Hemospray порівняно до інших ендоскопічних методів зупинки кровотеч у ШКТ.

Матеріали та методи. До когорти спостереження ввійшло 7 пацієнтів (чоловіків 5, жінок 2), віком 28-79 років (середній вік 52 7,1 років), які на першому етапі лікувались у Львівській обласній клінічній лікарні, хірургічному відділенні №3, хірургічному відділенні №2 а на другому - у гастроентерологічному відділен- ні ЛОКЛ в період з 2018 до 2019 рр (дозвіл біоетики комітету ЛНМУ № х від XXXX). Використовували відеоендоскоп Fujinone-250, кліпатори Hemoclips виробник Olympus. При зупинці кровотечі за рішенням хірурга-ендоскопіста порошковий гемостаз комбінувався 3 кліпуванням джерела кровотечі, послуговуючись сучасними рекомендаціями Європейської Асоціації Гастроентерологів (United European Gastroenterology) та Європейської Асоціації Ендоскопістів (European Society of Gastrointestinal Endoscopy), що вказують на необхідність виконання зупинки кровотечі в комбінації як мінімум двох методів (наприклад, кліпування та ін'єкційна зупинка або інші) [17, 18 ].

Нижче приводимо описи випадків гемостазу за допомогою Hemospray та в комбінації 3 кліпуванням.

\section{Клінічні випадки}

1. Пацієнт Б. 64 р., госпіталізований в ургентному порядку в хірургічне відділення №3 Львівської обласної клінічної лікарні із клінічною картиною шлунково-кишкової кровотечі: кількаразове блювання з домішками крові, бліді шкірні покриви, що покриті холодним липким потом. На момент госпіталізації: ЧСС-102/Хв., АТ- 90/60мм. рт. ст., ЧД-19/хв. Язик сухий, покритий білим нальотом. Живіт помірно піддутий, симетрич- 


Original research: Clinical sciences

\section{The risk of bleeding relapse depending on the degree of severity according to Forrest}

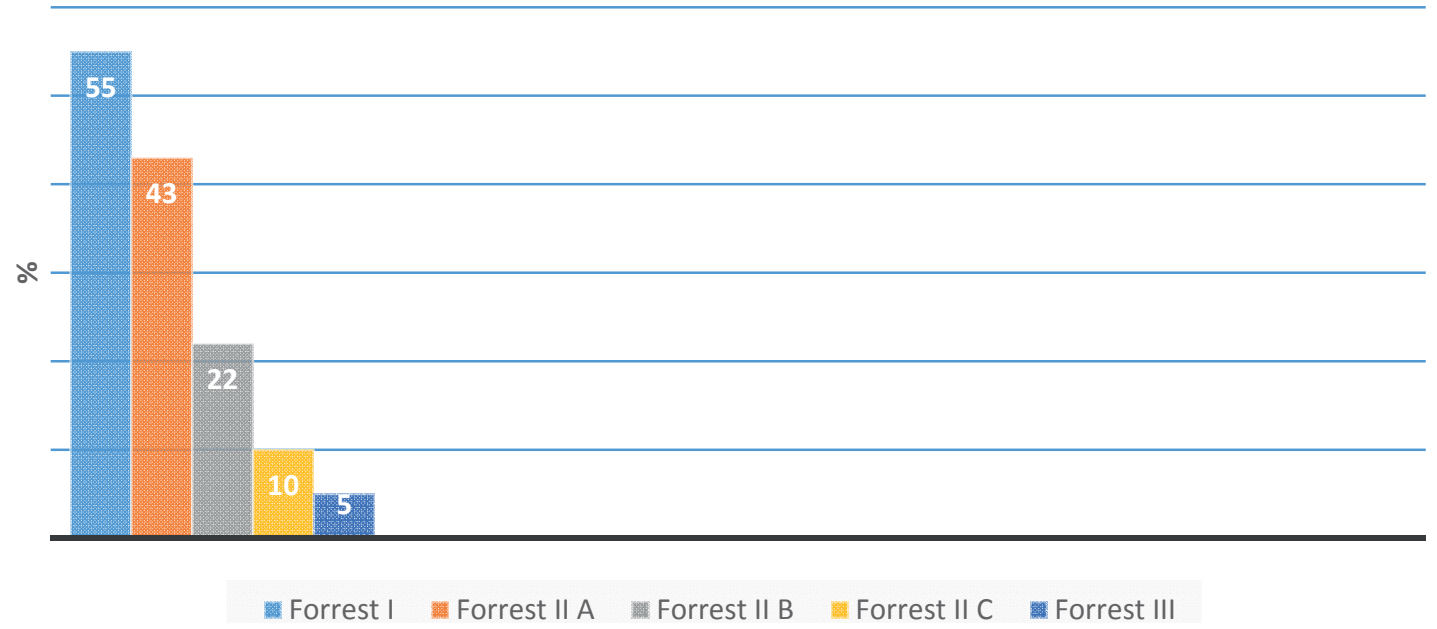

Figure 1 . The risk of bleeding relapse depending on the degree of severity according to Forrest (Laine \& Peterson WL.N. Engl. Med. 1994;331:717-27)

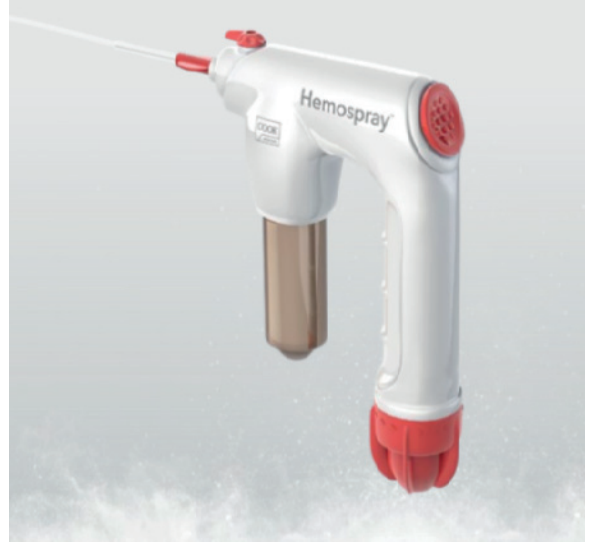

Figure 2. Hemospray - spray for endohemostasis

Aim of the paper. To study the efficiency of the method to stop bleeding using Hemospray in the conditions of endoscopic intervention. To describe the efficiency of such intervention method using Hemospray as compared to other endoscopic methods used to stop bleeding from the GIT.

Materials and methods. The observed cohort included 7 patients ( 5 men and 2 wom-

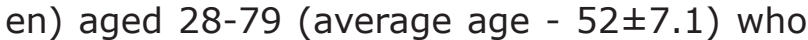
during the first stage received treatment at Lviv Regional clinical hospital, surgery department No. 3, surgery department No. 2, and during the second stage in 2018-2019 - at the gastroenterological department of Lviv Regional Clinical Hospital (the permission of the Bioethics Committee of Lviv National Medical University No. $x$ dated $X X X X)$. Video endoscope Fujinone-250 and clipping devices Hemoclips from Olympus were used. When the bleeding stopped, powder hemostasis was combined with clipping of the bleeding source upon the surgeon-endoscopist's decision. This procedure was applied in accordance with the recommendation of the United European Gastroenterology and European Society of Gastrointestinal Endoscopy that specify the need to stop bleeding using at least two methods (for example, clipping and injectable stopping, or other methods) $[17,18]$.

Below are descriptions of hemostasis cases using Hemospray and clipping.

\section{Clinical cases}

1. Patient B. 64, urgently hospitalized in the surgery department No. 3 of Lviv Region Clinical Hospital with a clinical pattern of gastrointestinal bleeding: multiple vomiting with blood traces, pale skin covered with cold sticky sweat. At the time of hospitalization: heart rate $-102 / \mathrm{min}$, blood pressure - 90/60 mm Hg, respiratory rate $-19 / \mathrm{min}$. Tongue dry, covered with white coating. The abdomen is moderately bloated, symmet- 
ний, доступний до пальпації у всіх відділах, не болючий. Симптоми подразнення очеревини від'ємні. У загальному аналізі крові: Er - 2.6 х10*12, Hb - 86г/л, Le- 4.7×10*9, В ургентному порядку виконано ВГДС: в шлунку масивні згортки та свіжа кров. Аспіровано згортки, промито порожнину шлунка та повторно аспіровано залишки геморагічного вмісту. Під час огляду в інверсії візуалізовано джерело шлункової кровотечі. Інфільтративно-виразковий дефект слизової шлунка в кардіальному відділі шлунка з-під висячого згортка верифіковано пульсуючу струйну кровотечу (артерія діаметром 2-3мм). За ендоскопічною класифікацією: Виразково - інфільтративний процес кардіального відділу шлунка? Шлункова кровотеча Forrest I А. Локалізація та анатомічні особливості не давали змоги накласти кліпси чи використати прицільно електрокоагуляцію. Вперше в Україні виконано ендоскопічну зупинку кровотечі з допомогою засобу Hemospray (рис. 3 а,6,в.). Втручання тривало до 10 хвилин.

Після ендоскопічної зупинки кровотечі пацієнт отримував інгібітори протонової помпи (езомепразол) та інфузійнну терапію в реко- мендованих стандартних дозах та перебував в умовах хірургічного стаціонару під динамічним спостереженням та контролем гемостазу. Клінічної картини рецидиву кровотечі не було. Гемодинамічні показники були стабільні. Через 24 год. виконано контрольний ВГДС огляд: в шлунку просвіт без геморагічного вмісту, виявлено свіжі нашарування фібрину, що вкривали дефект слизової L=12-14 мм., без ознак рецидиву кровотечі (рис. 4).

Взято біопсію при контрольному огляді із зони зміненої слизової з кардіального відділу шлунка. Гістологічне заключення : G2 аденокарцинома шлунка. Без рецидиву кровотечі був виписаний із стаціонару на 5 добу. Виконано КТ, що підтвердило локальне потовщення стінки шлунка в кардіальному відділі без поширення на стравохід та вторинних уражень інших органів. Через 2 тижні виконано радикальне хірургічне втручання в хірургічному відділенні №3 Львівської обласної клінічної лікарні в об'ємі: Гастектомія. Езофагоентероанастомоз. Пацієнт на 7 добу виписаний з стаціонару в доброму стані. Перебуває під динамічним спостереженням хірургів, гастроентерологів та онкологів.

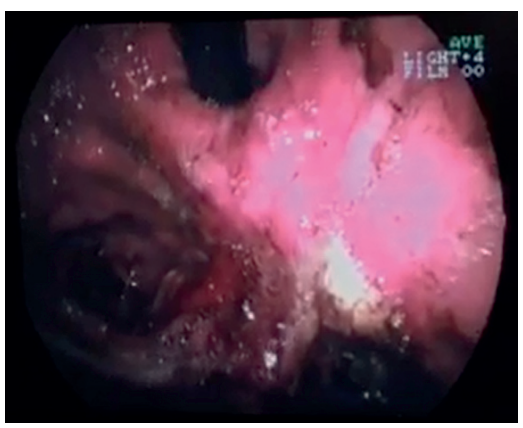

a

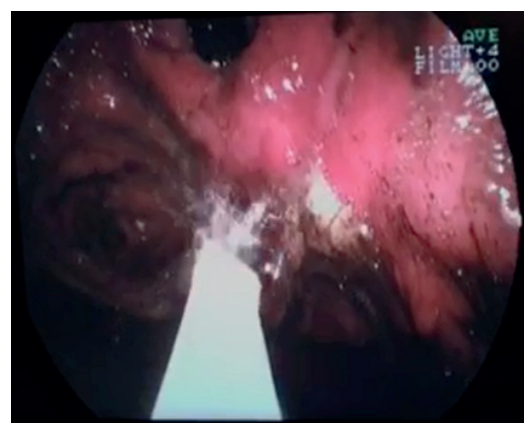

6

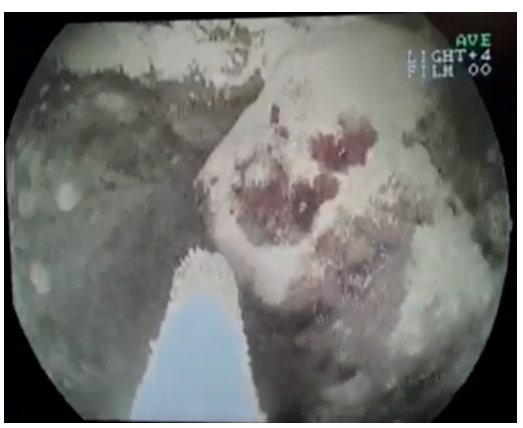

B

Рис. 3. ВГдС огляд в інверсії та поетапна зупинка засобом Hemospray (a,6,в)

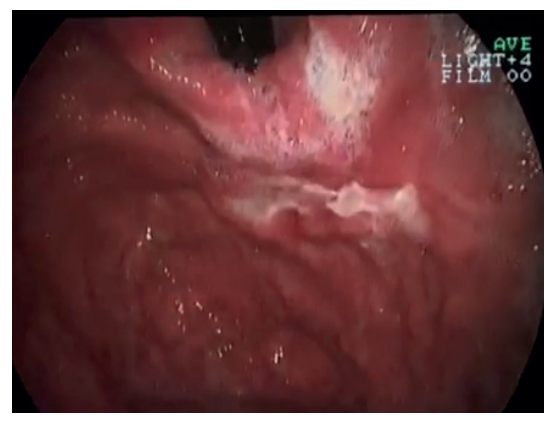

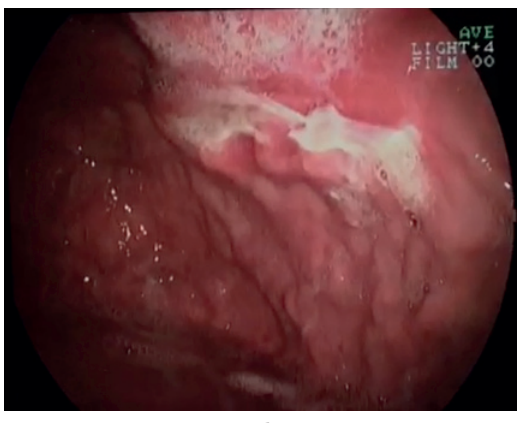

6

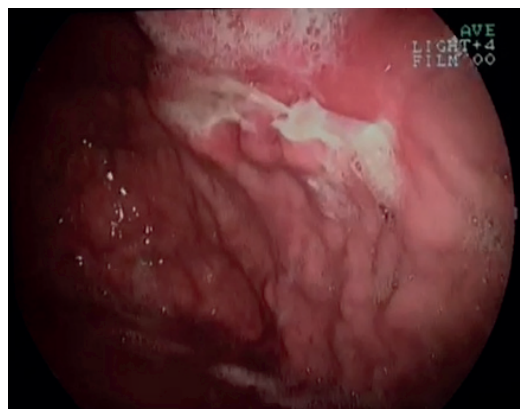

B

Рис. 4. ВГДС контрольний огляд через 24 год після зупинки кровотечі засобом Hemospray $(\mathrm{a}, 6$, в) 
rical, may be palpated in all sections, not painful. The symptoms of peritoneal irritation are negative. Full blood count: $\mathrm{Er}-2.6$ $\mathrm{x} 10 * 12, \mathrm{Hb}-86 \mathrm{~g} / \mathrm{l}$, Le- $4.7 \times 10 * 9$. VDGS was performed urgently: there were massive blood clots and new blood in the stomach. Blood clots aspirated, gastric cavity was cleansed, and remaining hemorrhagic contents were aspirated again. During the examination, the source of gastrointestinal bleeding was visualized. Invasive ulcerous defect of the gastric mucosa in the forestomach, from under the hanging clot verified throbbing spurting bleeding (an artery with a diameter of 2-3 mm). According to endoscopic classification: Invasive ulcerous process of the forestomach. Gastric bleeding Forrest I A. Localization and anatomic peculiarities did not allow using clips or electrocoagulation. For the first time in Ukraine, bleeding was stopped endoscopically using Hemospray method (Figure $3 a, b, c)$. The invasion lasted up to 10 minutes.

After the bleeding was stopped endoscopically, the patient received proton pump inhibitors (esomeprazole) and fluid therapy using stan- dard dosage. He stayed in the conditions of the surgery department under the dynamic observation and control of hemostasis. There was no clinical pattern of bleeding relapse. Hemodynamic indicators were stable. In 24 hours, a follow-up VGDS examination was performed: the stomach lumen had no hemorrhagic contents, new fibrin layers were detected, which covered the mucosa defect $L=12-14 \mathrm{~mm}$, with no signs of bleeding relapse (Figure 4).

During the follow-up examination, a biopsy was taken from the section of the changed forestomach mucosa. Histology Report: G2 gastric adenocarcinoma. The patient was discharged home on the $5^{\text {th }}$ day without repeated bleeding. CT was performed, which confirmed local thickening of the stomach wall in the cardiac portion with no spreading to the esophagus or secondary lesions of other organs. In two weeks, radical surgical intervention was made in the surgery department no. 3 of Lviv Region Clinical Hospital: Gastrectomy. Esophago enteroanastomosis. On the $7^{\text {th }}$ day, the patient was discharged in good condition. He is under the dynamic observation of surgeons, gastroenterologists, and oncologists.

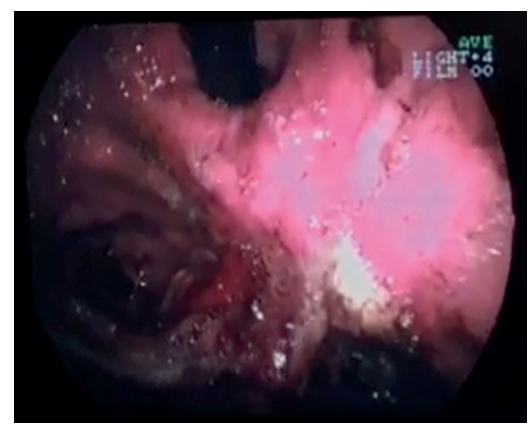

a

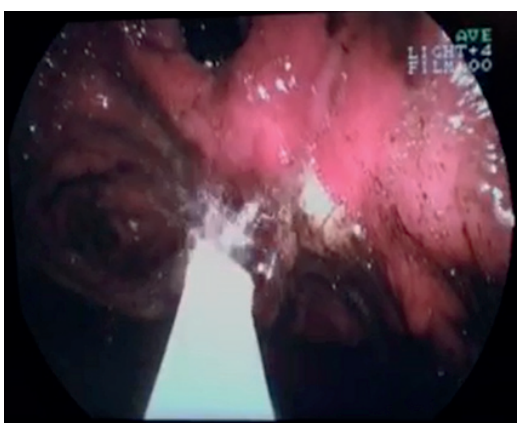

b

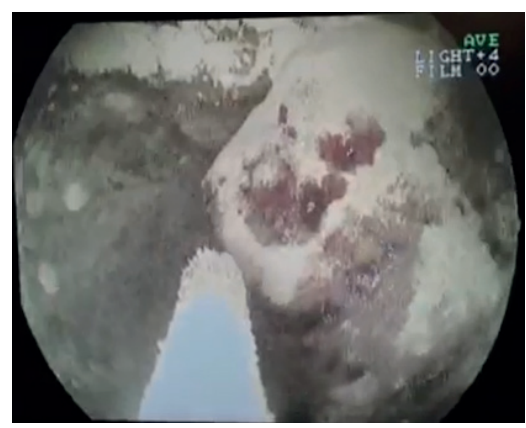

C

Figure 3. VGDS view of the inversion and staged stopping using Hemospray $(a, b, c)$

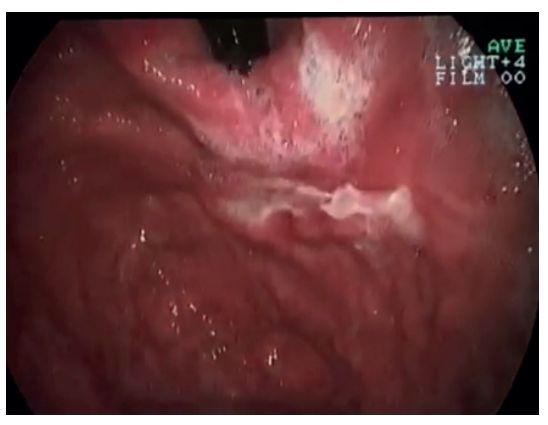

a

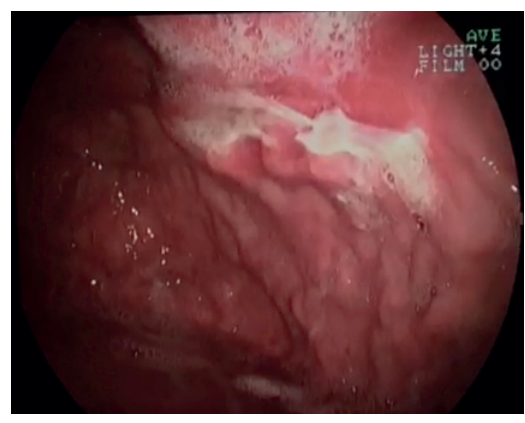

b

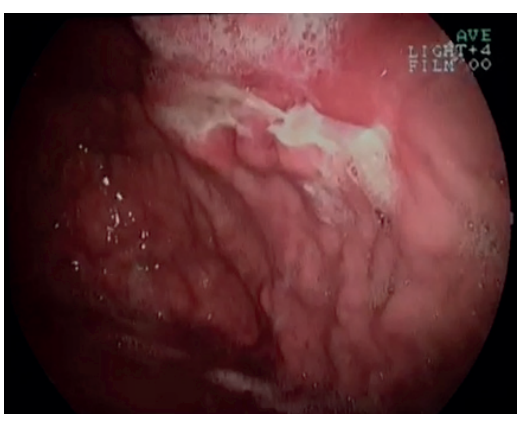

C

Figure 4. Follow-up VGDS examination in 24 hours after the bleeding was stopped using Hemospray (a, b, c) 
2. Пацієнт П. 43 р., був госпіталізований в хірургічне відділення №3 Львівської обласної клінічної лікарні із клінічною картиною шлунково-кишкової кровотечі: кількаразове блювання кров'ю, бліді шкірні покриви, що покриті холодним липким потом. На момент госпіталізації: ЧСС - 92/Хв., АТ 80/60 мм. рт. ст., ЧД - 22/хв. Язик сухий, покритий білим нальотом. Живіт болючий у лівому підребер'ї, в мезогастрії та епігастрії з іррадіацією в поперекову ділянку зліва, що чутлива під час пальпації. Симптоми подразнення очеревини від'ємні. Симптом Пастернацького від'ємний з обох сторін. 3 анамнезу : напередодні надсадне блювання, що не приносило полегшення, згодом блювання із геморагічним вмістом. Загальний аналіз крові: $\mathrm{Er}-3.4 \times 10 * 12, \mathrm{Hb}-106$ г/л, Le - 9.7×10*9, Біохімічні показники крові: амілаза - 230 од/л, ліпаза - 120 од/л, лужна фосфатаза 680 од/л. Діагноз під час госпіталізації: Хронічний панкреатит в стадії загострення, аліментарного генезу. Синдром Мелорі - Вейса? ВГДС: в страво- оході та шлунку геморагічний вміст. Візуалізовано джерело кровотечі на межі шлунково-стравохідного з'єднання два лінійні розриви: $L=25$ та 30 мм із капілярною кровотечею із країв розривів. Виконано ендогемостаз: ендокліпування країв розриву стінки шлунка (рис. 5 а, 6, в. Ендокліпування + Hemospray (рис. 5 г, д, е).

Пацієнт виписаний через 10днів зі стаціонару без рецидиву кровотечі, та після консервативного лікування основного захворювання - панкреатиту.

\section{Обговорення}

Представлені клінічні випадки свідчить про ефективність зупинки ургентних кровотеч ШКТ використанням засобу Hemospray, як у разі монотерапії, так і в комплексі із іншими ендоскопічними методами, про що свідчать результати інших накеових груп []. Ключові переваги такого методу: не потребує високої кваліфікації персоналу та вартісного інструментельно-технічного забезпечення.

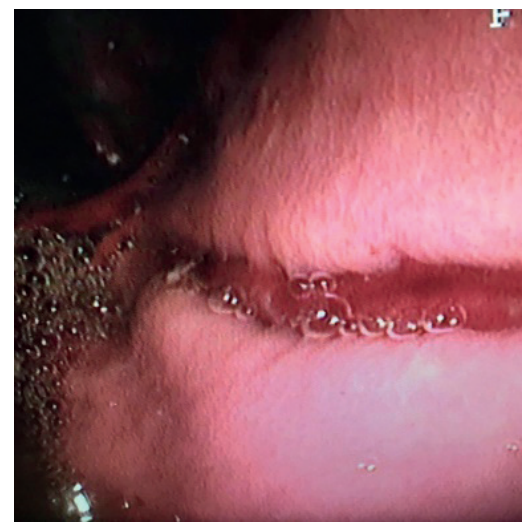

a

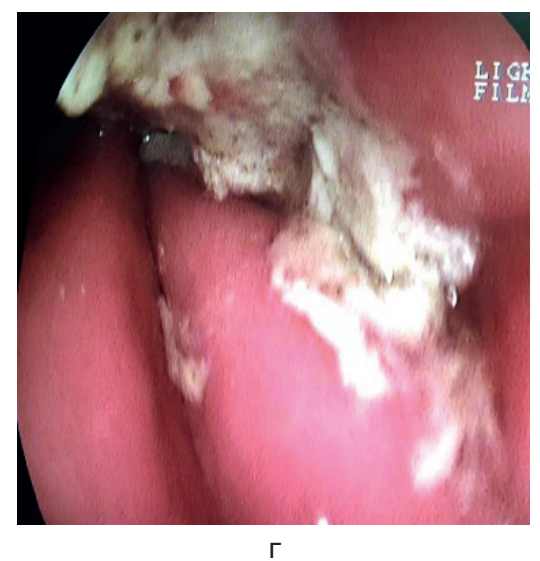

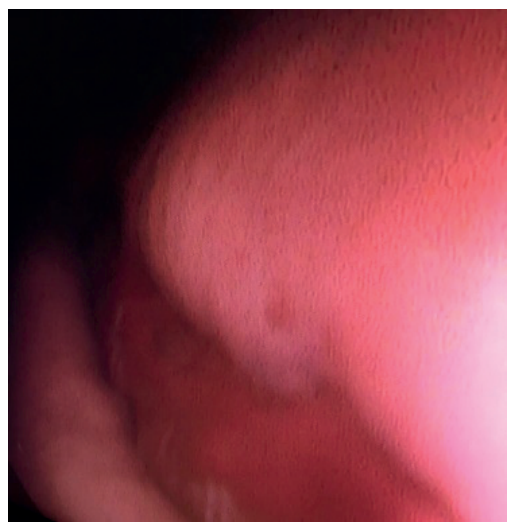

6

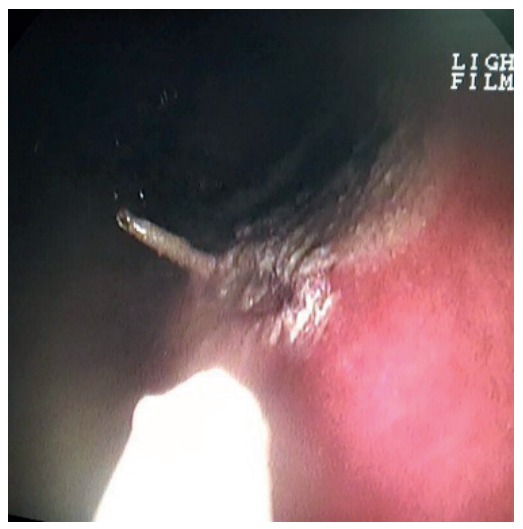

д

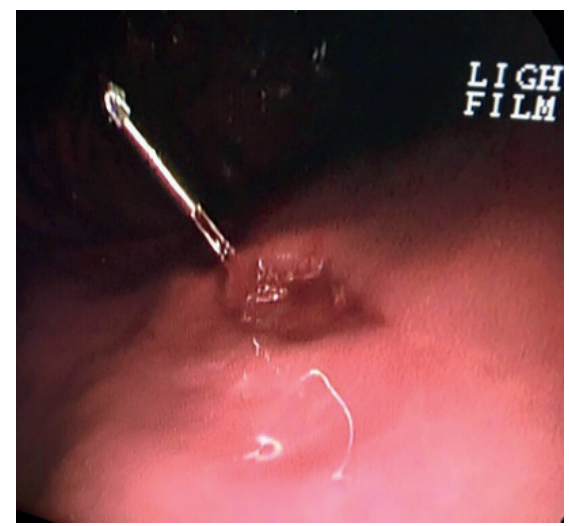

B

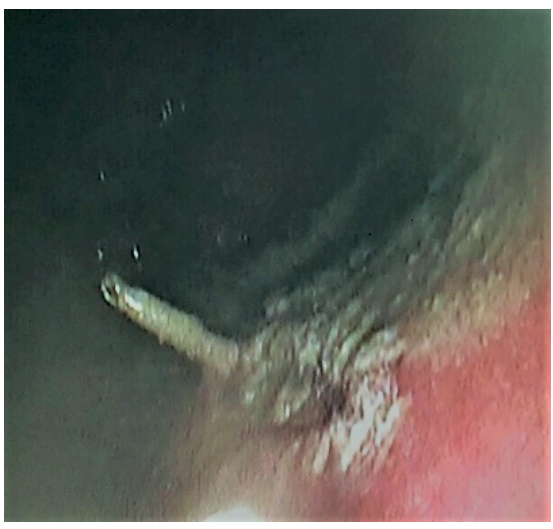

e

Рис. 5 Синдром Мелорі-Вейса (а,б), ендокліпування (в), Hemospray (г), Hemospray+ендокліпування (д, е) 
2. Patient P. 43, was hospitalized in the surgery department no. 3 of Lviv Region Clinical hospital with a clinical pattern of gastrointestinal bleeding: multiple vomiting with blood traces, pale skin covered with cold sticky sweat. At the time of hospitalization: heart rate - 92/ min, blood pressure $-80 / 60 \mathrm{~mm} \mathrm{Hg}$, respiratory rate $-22 / \mathrm{min}$. The tongue is dry, covered with white coating. The abdomen is painful in the area of left hypochondrium, mesogaster and epigastrium with radiation to the lumbar region on the left, which is sensitive during palpation. Symptoms of peritoneal irritation are negative. Pasternatsky's symptom is negative on both sides. Anamnesis: heavy vomiting before hospitalization, which did not bring any relief; later vomiting with hemorrhagic contents. Full blood count: $\mathrm{Er}-3.4 \times 10^{* 12}$, $\mathrm{Hb}-106 \mathrm{~g} / \mathrm{l}$, Le - 9.7×10*9, Blood chemistry value: amylolytic enzyme - 230 units/l, lipase - 120 unit1s/l, alkaline phosphatase 680 units/l. Diagnosis at the time of hospitalization: chronic pancreatitis in the exacerbation phase, alimentary genesis. Mallory-Weiss syndrome? VGDS: hemorrhagic contents in the esophagus and stomach. Bleeding source visualized on the border of gastro-esophageal junction, two linear dilacerations: $L=25$ and $30 \mathrm{~mm}$ with capillary bleeding from the edges. Endo-hemostasis performed: endo-clipping of the edges of stomach wall dilaceration (Figure $5 \mathrm{a}, \mathrm{b}, \mathrm{c}$. Endo-clipping + Hemospray (Figure $5 d, e, f)$.

On the $10^{\text {th }}$ day, the patient was discharged from the in-patient department without repeated bleeding and after conservative treatment of the underlying disease - pancreatitis.

\section{Discussion}

Clinical cases presented show the efficiency of stopping urgent GIT bleeding with the help of Hemospray, both in the form of monotherapy and in the combination of other endoscopic methods, which is confirmed by the results of other scientific groups []. Key advantages of this method: it does not require any specific qualification of the staff or costly instrumen-

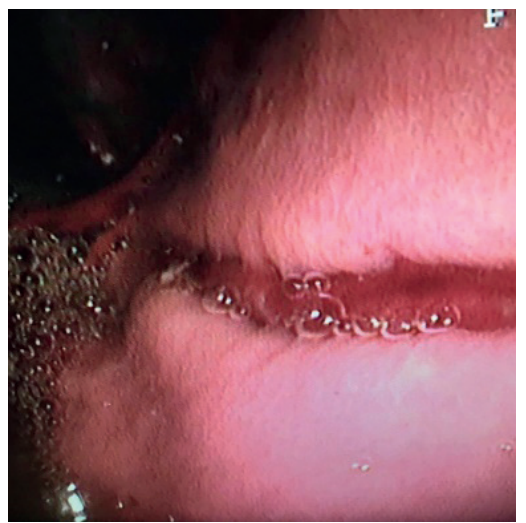

a

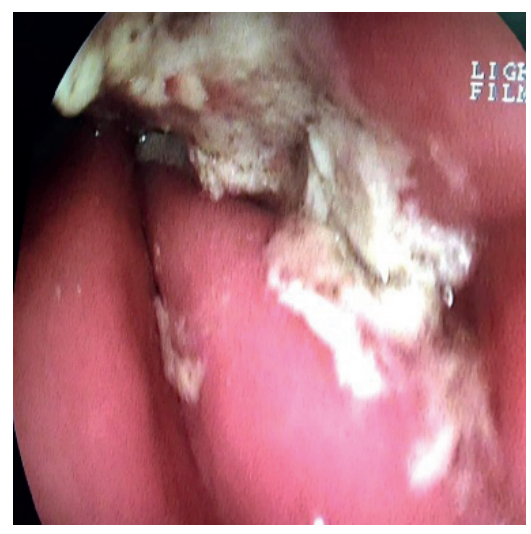

d

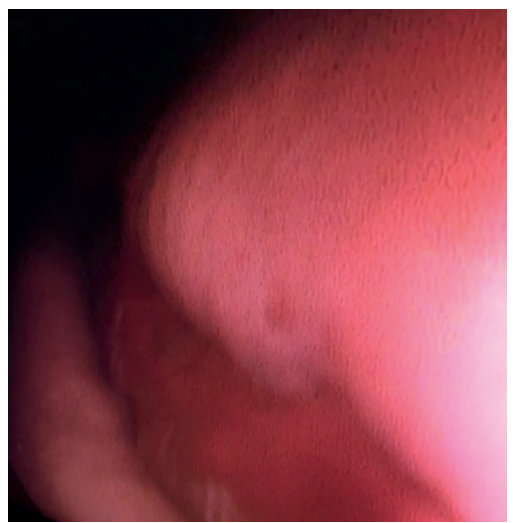

b

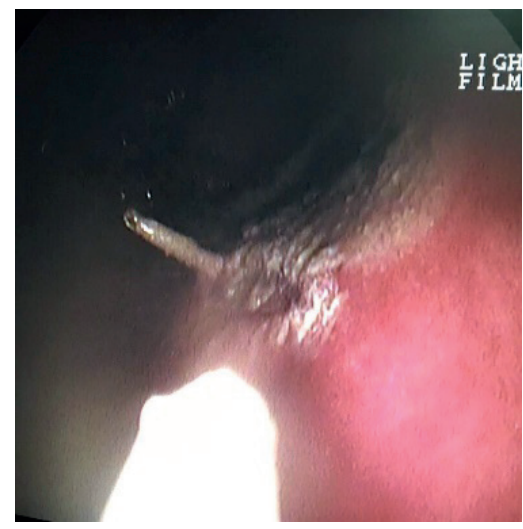

e

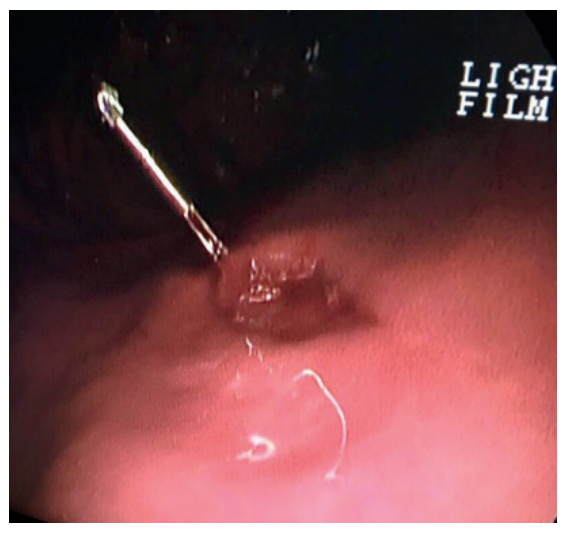

C

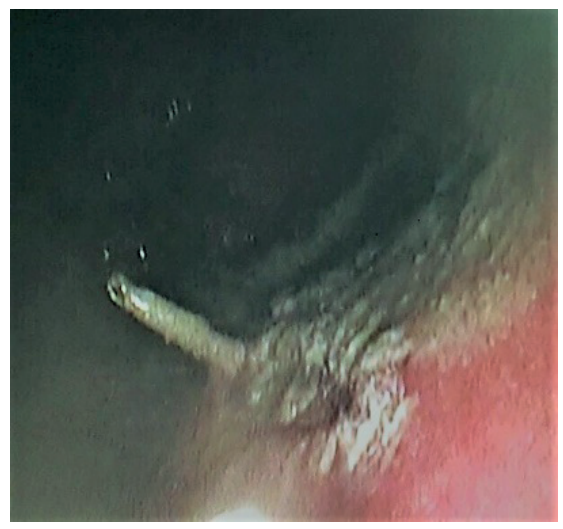

$\mathrm{f}$

Figure 5. Mallory-Weiss syndrome (a, b), endo-clipping (c), Hemospray (d), Hemospray + endo-clipping (e, f) 


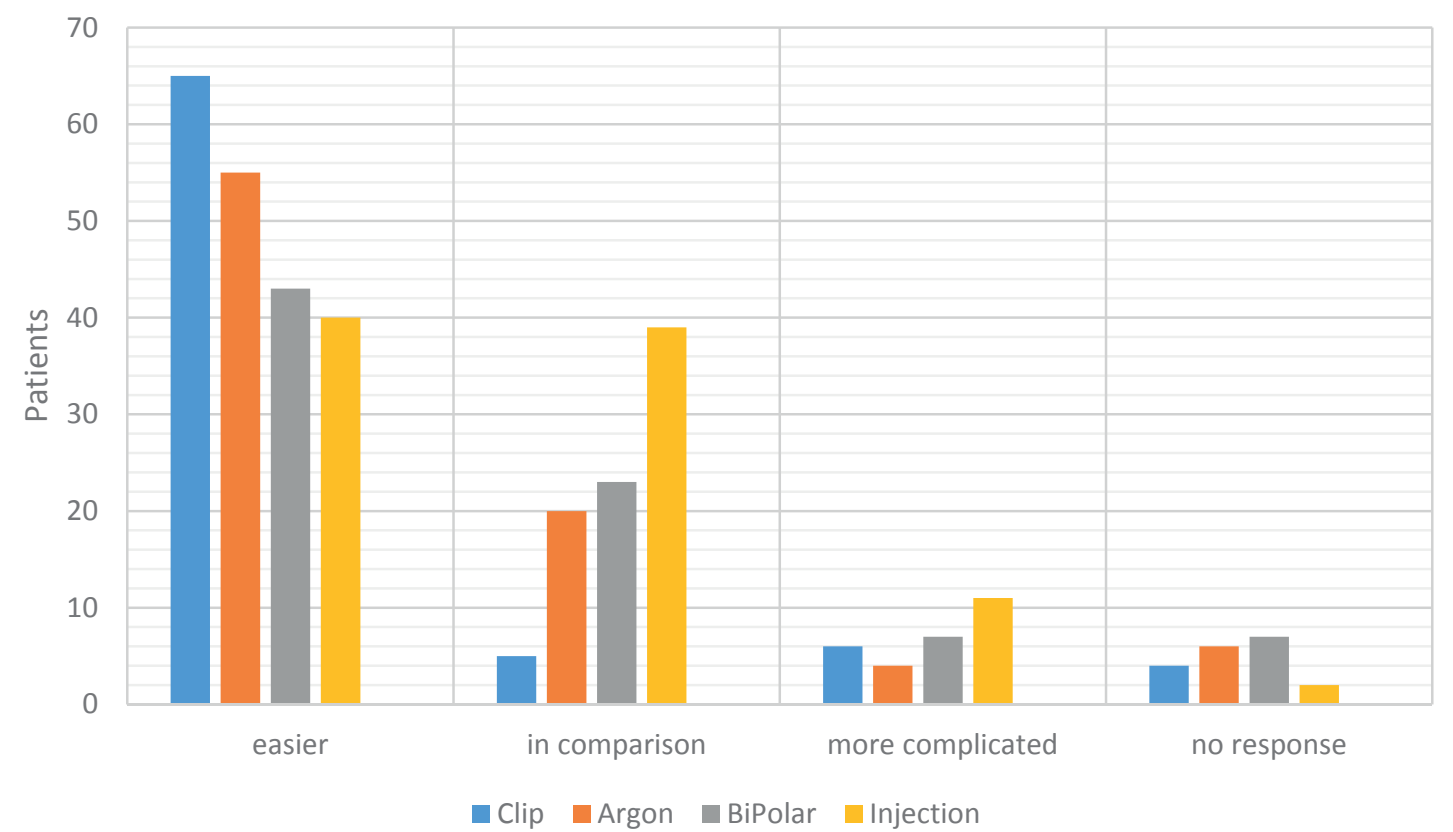

Рис. 6. Статистичні дані щодо затрати часу на ендоскопічні методи зупинки кровотечі [22].

Дає стійкий та тривалий гемостаз навіть за умов активних артеріальних кровотечах. Практично відсутні побічні дії препарату та можливість ятрогенних ускладнень (перфорації та інші). Препарат діє у короткий термін після застосування, зручний у використанні. За даними досліджень опублікованих в США, після опитування експертів що використовували гемостатики (у групі спостереження було залучено 79 пацієнтів), позитивний стійкий результат був досягнутий в 77\% випадків менше порівняно до ефектів Hemospray (ефект спостерігали через 10 хв після застосування). Більше половини з групи експертів (59 \%) ствердно вказали, що Hemospray економить час в порівнянні із іншими методами зупинки кровотечі (рис. 6)

Незважаючи на невелику кількість випадків, отримані дані дозволяють зробити висновки:

- описані клінічні випадки свідчить про високу ефективність зупинки ургентних кровотеч ШКТ використовуючи за- ci6 Hemospray як при монотерапії, так і в комплексі із іншими ендоскопічними методами;

- засіб Hemospray має наступні ключові переваги над іншими ендоскопічними методами: безтермічний - немає термічного контакту із тканинами, що унеможливлює високий ризик ускладнень; нетравматичний - оскільки на місці зупинки кровотечі не прикладається жодна сила зводиться до нуля ризик травми тканин; безконтактний - аерозольна система доставки виключає необхідність прямих механічних та контактних сил; безпечний у вжитку - одноразові канюлі що йдуть в комплекті - унеможливлюють ризик передачі інфекційних захворювань при контакті з кров'ю; зручність та легкість у використанні - порошок розпорошується до джерела кровотечі, тому він не вимагає підходу in face та точного націлювання зокрема важливо при роботі у важкодоступних місцях.

\section{Література / References}

1. Holster L, Van Beusekom H, Kuipers E, Leebeek F, Maat M, Tjwa E. Effects of a hemostatic powder hemospray on coagulation and clot formation. Endoscopy 2015; 47 (07): 638-645//DOI: 10.1055/s0034-1391353

2. Arena M, Masci E, Eusebi LH, Iabichino G. Hemospray for treatment of acute bleeding due to upper gastrointestinal tumours. Digestive and Liver Disease Volume 49, Issue 5, May 2017, Pages 514-517 https://doi.org/10.1016/j.dld.2016.12.012 


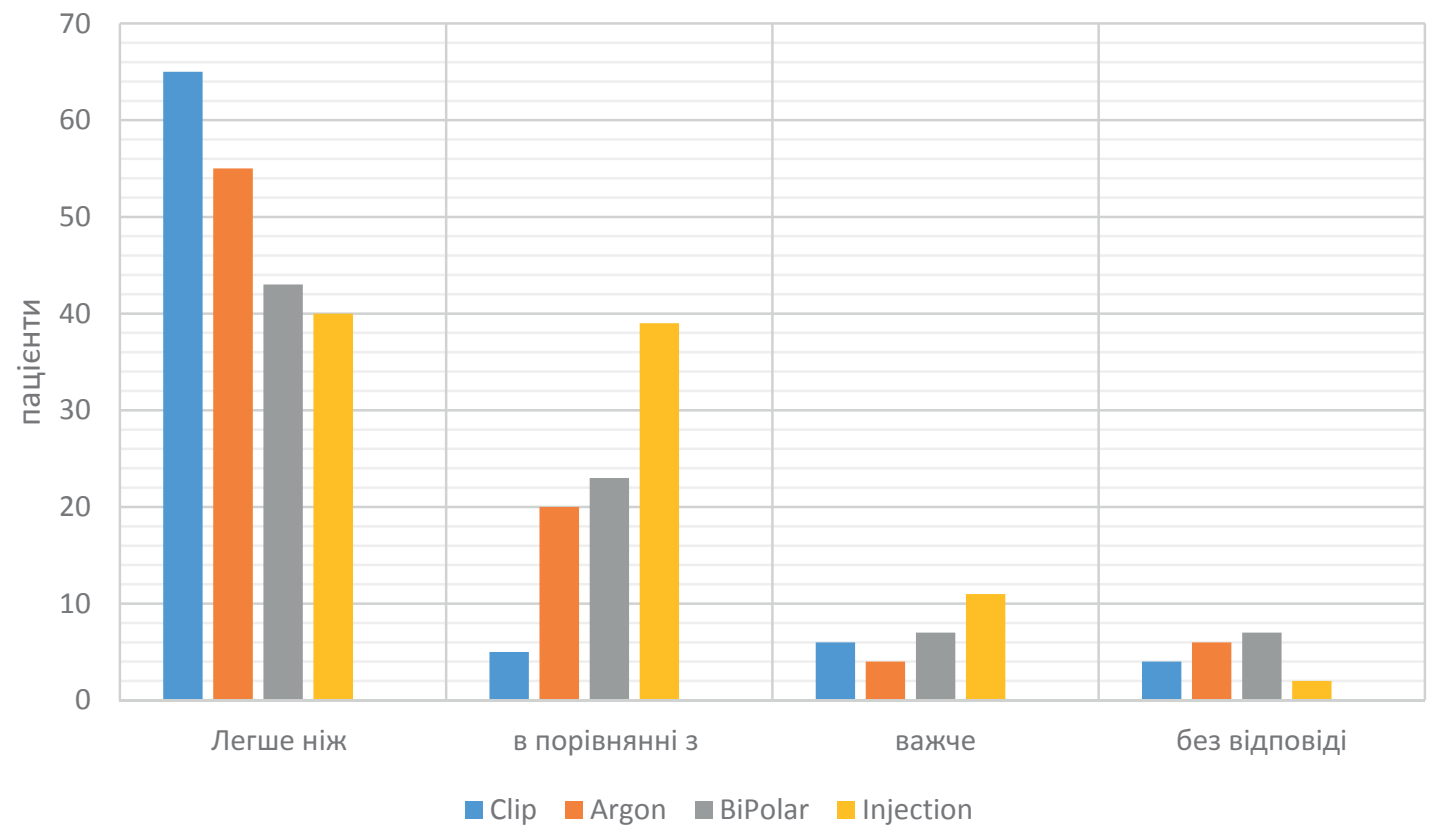

Figure 6. Statistical data on the time needed for endoscopic methods used to stop bleeding [22].

tal and technical equipment. It provides stable and long-lasting hemostasis even under the conditions of arterial bleeding. Adverse effects of the method and the possibility of treatment-induced complications (bursting and others) are almost absent. The effects start shortly after application, it is easy to use. Based on the research published in the USA, which was based on surveying experts using hemostasis (79 patients were involved in the observation group), positive results were achieved in $77 \%$ fewer cases as compared to Hemospray (the effect was observed already in 10 min after application). Over half of the expert group (59\%) agreed that Hemospray saves time as compared to other methods used to stop bleeding (Figure 6)

Despite the small number of cases, the data obtained let us make the following conclusions:

- Described clinical cases confirm the high efficiency of urgent GIT bleeding using Hemo- spray both as monotherapy and in combination with other endoscopic methods.

- Hemospray has the following key advantages over other endoscopic methods: non-thermal - there is no thermal contact with tissues, which makes it impossible for the high risk of complications to appear; non-traumatic - since no pressure is applied to the bleeding site, the risk of tissue injury is reduced to zero; non-contact - aerosol system of application excludes the need for direct mechanical and contact pressure; safe - disposable cannulas included in the kit make it impossible to transmit infectious diseases when there is contact with blood; convenience and ease of use - the powder is sprayed over the source of bleeding, therefore there is no need for in face approach and accurate targeting, including when administering it to the hard to reach areas.

3. Francesco V, Naegel A, Atreya R, Zopf S, et at. Comparison of Hemospray ${ }^{R}$ and Endoclot ${ }^{\mathrm{TM}}$ for the treatment of gastrointestinal bleeding. World J Gastroenterol. 2019 Apr 7; 25(13): 1592-1602.//Doi: 10.3748/wjg.v25.i13.1592

4. Hagel A, Albrecht H, Nägel A, Vitali F,Vetter M, Dauth C, Neurath M, and Martin Raithe. The Application of Hemospray in Gastrointestinal Bleeding during Emergency Endoscopy. Gastroenterology Research and Practice.Volume 2017, Article ID 3083481, 8 pages. https://doi.org/10.1155/2017/3083481

5. Eusebi L, Arena M, Despott E, Masci E, Iabichino G, Mangiavillano B, Viaggi P, Morandi E, Fanti L, Granata A, Traina M. Acute Bleeding Due to Upper Gastrointestinal Tumors Treated With Hemospray: A Case Series From 4 European Endoscopy Centers. GIE. May 2017Volume 85, Issue 5, Supplement, Pages AB457-AB458 
DOI: https://doi.org/10.1016/j.gie.2017.03.1065

6. Curcio G, Barresi L, Ligresti D, Tarantino I, Orlando R, Traina M. Hemospray rescue treatment of severe refractory bleeding associated with ischemic colitis: a case series. International Journal of Colorectal Disease. March 2016, Volume 31, Issue 3, pp 719-720

7. Alzoubaidi D, Magee C, Gulati S, Haji A, Morris J, Lovat L, Hayee B, Haidry R. Outcomes from an international multicentre registry of patients with gastrointestinal bleeding undergoing endoscopic treatment with hemospray. BMJ Journals. Volume 66, Issue Suppl 2

8. Kosasih S, Jalihal A, Chong VH. Maximizing the use of Hemospray. Indian Journal of Gastroenterology. September 2018, Volume 37, Issue 5, pp 467-468

9. Xavier S, Magalhães J, Rosa B, Cotter J. Hemospray use in upper gastrointestinal bleeding from tumor: Is it the answer? Endosc Int Open 2016; 04(12): E1331-E1332// DOI: 10.1055/s-0042-121800

10. Pittayanon R, Prueksapanich P, Rerknimitr R. The efficacy of Hemospray in patients with upper gastrointestinal bleeding from tumor. Endosc Int Open 2016; 04(09): E933-E936// DOI: 10.1055/s0042-109863

11. Gubler C, Turina M. Hemospray treatment for bleeding intestinal anastomoses in the early postoperative period: a novel non-operative approach. Techniques in Coloproctology. July 2016, Volume 20, Issue 7, pp 495-498

12. Vitali F, Näge A, Siebler J, Neurath MF, Rath T. Efficacy of hemospray and and endoclot in the treatment of gastrointestinal bleeding: results from a tertiary referral center. Endoscopy 2018; 50(04): S7// DOI: 10.1055/s-0038-1637044

13. Santiago R, Santamaría B, Carazo P, Lantaron T, Brullet E, Leira P, Pons R, Sainz F. Hemospray for gastrointestinal bleeding: effectiveness, predictors of failure and survival in a nationwide study. Endoscopy 2019; 51(04): S62// DOI: 10.1055/s-0039-1681353

14. Cahyadi O, Bauder M, Meier B, Caca K, Schmidt A. Effectiveness of TC-325 (Hemospray) for treatment of diffuse or refractory upper gastrointestinal bleeding - a single center experience. Endosc Int Open 2017; 05(11): E1159-E1164// DOI: 10.1055/s-0043-118794

15. Nasr I, Martino S, Borrow DM, Campling H, Koumoutsos I, Chia C, Dunn J. Hemospray: When Should We Plug the Gap? A Single Centre UK Experience. GIE. May 2016Volume 83, Issue 5, Supplement, Pages AB500-AB501// DOI: https://doi.org/10.1016/j.gie.2016.03.720

16. Cockerel C, Parsa N, Matteson-Kome M, Samiullah S, Nguyen D, Puli S, Bechtold M. Hemospray monotherapy for non- varieceal upper GI bleeding: a meta-analysis. June 2019Volume 89, Issue 6, Supplement, Page AB558// DOI: https://doi.org/10.1016/j.gie.2019.03.951

17. Kwek A, Ang T, Ong PL, Tan YL, Ang D, Law N, Thurairajah P, Fock K. Hemospray Versus the Combined Conventional Technique for Endoscopic Treatment of Bleeding Peptic Ulcers: A Pilot Randomized Controlled Study. GIE. May 2016Volume 83, Issue 5, Supplement, Pages AB123-AB124// DOI: https:// doi.org/10.1016/j.gie.2016.03.040

18. Uday A, Jothimani S, Rela M. Hemospray for Recurrent Oesophageal Band Ulcer Bleeding. Journal of Clinical and Experimental Hepatology. July 2017Volume 7, Supplement 2, Page S95

19. Appleby R, Hoare J. Hemospray in a large tertiary nhs trust: a descriptive analysis of the first three years of use. . Gut, suppl.2 ; London Vol. 66, (Jul 2017): A216. DOI:10.1136/gutjnl-2017-314472.419

20. Ivekovic $H$, Bilic B,Markos P, Rustemovic N, Ostojic R, Mönkemüller K. Successful use of Hemospray to control refractory post-polypectomy bleeding. Endoscopy 2015; 47(S 01): E466-E467// DOI: 10.1055/ s-0034-1392865

21.Venezia G, Asnaghi G, Manca A, Ghezzo L. Successful use of Hemospray as a bridge to surgery in lifethreatening bleeding from a gastrointestinal stromal tumor of the stomach. Endoscopy 2016; 48(S 01): E232-E233//DOI: $10.1055 / \mathrm{s}-0042-109600$

22. Smith, L. A., Stanley, A. J., Bergman, J. J., Kiesslich, R., Hoffman, A., Tjwa, E. T., ... \& Schmidt, P. N. Hemospray application in nonvariceal upper gastrointestinal bleeding: results of the Survey to Evaluate the Application of Hemospray in the Luminal Tract. Journal of clinical gastroenterology 2014, 48(10), e89-e92. 